\title{
Recurrence rates of urinary calculi according to stone composition and morphology
}

\author{
Michel Daudon $^{1,2}\left(\right.$ Paul Jungers $^{3} \cdot$ Dominique Bazin $^{4,5} \cdot$ James C. Williams Jr. ${ }^{6}$
}

\begin{abstract}
Few studies have examined the relative risk of recurrence of different stone types. The object of the present study was to evaluate the tendency for stone recurrence as a function of major mineral composition of the stones and morphological characteristics of the stones. This study was carried out using 38,274 stones for which we had data available to specify if the stone was from the first or a subsequent urinary stone episode. Stones were analyzed for morphology by stereomicroscope and for composition by infrared spectroscopy. Overall, $42.7 \%$ of stones were from patients who had had a previous stone event, with these being more frequent in men $(44.4 \%)$ than in women $(38.9 \%, p<0.0001)$. Age of first stone occurrence was lowest for dihydroxyadenine ( $15.7 \pm 16.6$ years) and highest for anhydrous uric acid ( $62.5 \pm 14.9$ years), with the average age of first stones of calcium oxalate falling in the middle ( $40.7 \pm 14.6$ years for calcium oxalate dihydrate, and $48.4 \pm 15.1$ years for calcium oxalate monohydrate, COM). By composition alone, COM was among the least recurrent of stones, with only $38.0 \%$ of COM stones coming from patients who had had a previous episode; however, when the different morphological types of COM were considered, type Ic — which displays a light color, budding surface and unorganized section—had a significantly greater rate of recurrence, at $82.4 \%(p<0.0001)$, than did other morphologies of COM. Similarly, for stones composed of apatite, morphological type IVa2 - a unique form with cracks visible beneath a glossy surface — had a higher rate of recurrence than other apatite morphologies ( 78.8 vs. $39-42 \%, p<0.0001)$. Stone mineral type alone is insufficient for identifying the potential of recurrence of the stones. Instead, the addition of stone morphology may allow the diagnosis of highly recurrent stones, even among common mineral types (e.g., COM) that in general are less recurrent.
\end{abstract}

Keywords Urinary stone $\cdot$ Stone analysis $\cdot$ Morphology $\cdot$ Recurrence

Michel Daudon

michel.daudon@aphp.fr

1 Laboratoire des Lithiases, Service des Explorations Fonctionnelles Multidisciplinaires, Hôpital Tenon, APHP, 4, rue de la Chine, 75970 Paris Cedex 20, France

2 Unité INSERM UMRS 1155, UPMC, Hôpital Tenon, Paris, France

3 Département de Néphrologie, Hôpital Necker, APHP, Paris, France

4 LCMCP, UPMC, CNRS, Collège de France, Paris, France

5 Laboratoire de Physique des Solides, Université Paris Sud, Orsay, France

6 Department of Anatomy and Cell Biology, Indiana University, Indianapolis, IN, USA

\section{Introduction}

Epidemiological studies on rates of stone occurrence and recurrence in industrialized countries agree on two points: first, urinary stones strike men more often than women and, second, recurrence of at least one more stone occurs in $40-50 \%$ of affected persons [1-3]. However, few studies have examined the relative risk of recurrence of different stone types. It seems reasonable to state that cystine stone disease, because of its genetic basis, leads to greater stone recurrence than most other types of stone disease [4]. Similarly, uric acid stones in older patients are often quite recurrent [5]. However, it is not so clear what to say about the stones composed of calcium salts. For calcium oxalate, studies from some years ago suggest that weddellite (calcium oxalate dihydrate, COD) stones are more likely to recur than whewellite (calcium oxalate monohydrate, COM) stones [6], and that stones with a significant component of calcium 
phosphate are more likely to recur than stones composed of pure calcium oxalate [7]. The object of the present study was to evaluate the tendency for stone recurrence as a function of the major mineral composition of the stones, but also to take into account the morphological characteristics of the stones and the sex of the patient.

\section{Materials and methods}

This study was carried out using 38,274 stones collected from all regions of France for which we have data on both stone recurrence and the patient's age at the first stone episode. The stones were analyzed for morphology and composition (by infrared spectroscopy, as previously described $[8,9])$. Briefly, stones were examined using a stereomicroscope and each was classified according to the established morphological criteria $[9,10]$. These criteria include the appearance of the stone surface but also the appearance of the stone interior after the stone was cleaved one or more times to reveal its presumed nidus. The main characteristics of the stones are summarized in Table 1 and some examples of stone types are given in Fig. 1. Following these visual observations, samples of stone material were dissected away for analysis by Fourier transform infrared spectroscopy. For each stone, patient data were available to specify if this was from the first or a subsequent stone episode. The results are expressed according to the principal constituent, morphological type, and structural characteristics of the stone, and separated according to the sex of the patient.

Statistical comparisons were carried out using ANOVA and Chi-squared tests, as appropriate, using NCSS software (NCSS, Kaysville, Utah, USA).

\section{Results}

Of the 38,274 stones, coming from 26,368 males $(68.9 \%)$ and 11,906 females, $16,336(42.7 \%)$ were from patients who had had a previous stone event. Of these patients with recurrent stones, 11,702 were male and 4634 female, illustrating the fact that recurrent stones were more frequent in men than in women (44.4 vs $38.9 \%$ of the total for each sex, $p<0.0001)$. The mean age of patients with recurrent stones did not differ between the sexes $(45.0 \pm 14.3$ years old for men, $44.0 \pm 14.8$ for women).

\section{Mean age at first stone as a function of stone mineral}

We first consider the data on patients' initial stone events, looking at the age of first stone occurrence for the different crystalline species. The data are shown in Table 2, where, for each majority stone component, the mean age of the patients is given for each sex, with the stone components listed according to the increasing mean age of first occurrence. It is striking that the first five compositions listed in Table 2that is, the stone types occurring at the earliest ages-are crystalline species that are relatively rare, representing $<5 \%$ of all stones [10,11]. We are aware that the small number of samples in these groups is a limiting factor for the significance of the data regarding these stones. However, as expected, due to their inherited origin, the first groups of calculi are dihydroxyadenine and cystine. The crystalline species occurring at the youngest age is dihydroxyadenine. The second species is cystine, followed by octacalcium phosphate and whitlockite, then ammonium urate. Coming next in the table are more common types of stone, the first of which is COD, the calcium-dependant type of calcium oxalate [12-14]. The mean age at which this crystalline species appeared as a stone was 40 years, eight years younger than the mean age for COM stones, the other form of calcium oxalate. The distribution of calcium oxalate stones according to the crystalline phase and the patient's age and gender at the onset of the disease is illustrated in Fig. 2.

Between COD and COM are four forms of phosphate stone. Finally, the species appearing latest in life are the two forms of uric acid. The distribution of uric acid stones according to the patient's age and gender at the onset of the disease is shown in Fig. 3.

\section{Frequency of stone recurrence as a function of principal component}

Table 3 shows the proportion of patients having a recurrent stone episode (that is, the second or later stone episode for the patient) for each principal stone component. Within this, the stone components are ranked according to the increasing proportion of recurrent stones. Among the stone mineral types that have the lowest percentage of recurrence, two are phosphate stones, including struvite. However, among the seldom-recurring stones is also COM, the constituent most commonly found in urinary stones [10, 15, 16]. All the stone compositions that follow struvite in the table-with the exception of COD in men and women, and carbapatite and octacalcium phosphate in women-are more recurrent than the average percentage for all stones. Among these more-recurrent compositions, the two forms of uric acid appear at the head with a percentage of recurrence above $50 \%$, significantly higher than the average percentage for all stones. Finally, the three species at the bottom of Table 3 are particularly recurrent, apparently all forms of stone caused by very active metabolic processes: These are brushite, cystine, and dihydroxyadenine.

For stones of calcium oxalate, brushite and cystine, we have also recorded the number of stone episodes in the 
Table 1 Morphoconstitutional classification of urinary calculi (from $[9,10]$ )

\begin{tabular}{|c|c|c|c|c|}
\hline \multirow[t]{2}{*}{ Morphological type } & \multirow[t]{2}{*}{ Subtype } & \multirow[t]{2}{*}{ Main components } & \multicolumn{2}{|c|}{ Main morphological characteristics (for more details, see $[9,10]$ ) } \\
\hline & & & Surface & Section \\
\hline \multirow[t]{5}{*}{ I } & Ia & Whewellite & Mammillary, brown & $\begin{array}{l}\text { Concentric, radiating organization, } \\
\text { brown }\end{array}$ \\
\hline & $\mathrm{Ib}$ & Whewellite & Rough and mammillary, brown & Unorganized, brown \\
\hline & Ic & Whewellite & Budding, cream to pale yellow-brown & $\begin{array}{l}\text { Poorly organized, cream to pale yel- } \\
\text { low-brown }\end{array}$ \\
\hline & Id & Whewellite & Smooth, beige or pale brown & Concentric, compact, beige \\
\hline & $\mathrm{Ie}$ & Whewellite & $\begin{array}{l}\text { Locally budding and mammillary, } \\
\text { pale yellow-brown to brown }\end{array}$ & $\begin{array}{l}\text { Locally unorganized, locally radiating } \\
\text { organization, pale yellow-brown to } \\
\text { brown }\end{array}$ \\
\hline \multirow[t]{3}{*}{ II } & IIa & Weddellite & $\begin{array}{l}\text { Bipyramidal crystals aggregated, with } \\
\text { sharp angles and ridges, pale yellow }\end{array}$ & Loose radial organization, pale yellow \\
\hline & $\mathrm{IIb}$ & Weddellite \pm whewellite & $\begin{array}{l}\text { Bipyramidal crystals aggregated, } \\
\text { with blunted angles and ridges, pale } \\
\text { yellow }\end{array}$ & Unorganized, pale yellow \\
\hline & IIc & Weddellite & Rough, grey-beige & $\begin{array}{l}\text { Thin layers in periphery, unorganized } \\
\text { core, grey-beige }\end{array}$ \\
\hline \multirow[t]{4}{*}{ III } & IIIa & Uric acid & Smooth, ochre to orange & $\begin{array}{l}\text { Concentric, radiating organization, } \\
\text { orange }\end{array}$ \\
\hline & IIIb & Uric acid & $\begin{array}{l}\text { Embossed, rough and porous, beige } \\
\text { to orange }\end{array}$ & $\begin{array}{l}\text { Unorganized or poorly organized and } \\
\text { porous, orange }\end{array}$ \\
\hline & IIIc & Various urates & $\begin{array}{l}\text { Rough, locally porous, beige to grey- } \\
\text { ish }\end{array}$ & $\begin{array}{l}\text { Unorganized with porous areas, beige } \\
\text { to greyish }\end{array}$ \\
\hline & IIId & Ammonium urate & $\begin{array}{l}\text { Embossed, rough and porous, grey- } \\
\text { brown }\end{array}$ & $\begin{array}{l}\text { Alternated layers, thick and brownish, } \\
\text { thin and greyish }\end{array}$ \\
\hline \multirow[t]{5}{*}{ IV } & IVa1 & Carbapatite & $\begin{array}{l}\text { Rough or slightly embossed, cream } \\
\text { to beige }\end{array}$ & Poorly organized, whitish to cream \\
\hline & IVa2 & Carbapatite & $\begin{array}{l}\text { Embossed, glazed with cracks, yel- } \\
\text { low-brown }\end{array}$ & $\begin{array}{l}\text { Alternated layers, thick and yellow- } \\
\text { brown, thin and cream }\end{array}$ \\
\hline & $\mathrm{IVb}$ & Carbapatite & $\begin{array}{l}\text { Heterogenous, both embossed and } \\
\text { rough } \\
\text { Heterogenous color, cream to brown }\end{array}$ & $\begin{array}{l}\text { Alternated layers, thick and cream, thin } \\
\text { and yellow-brown }\end{array}$ \\
\hline & IVc & Struvite & $\begin{array}{l}\text { Amalgamate crystals with blunted } \\
\text { angles and thick ridges, whitish }\end{array}$ & Crude radial crystallization, whitish \\
\hline & IVd & Brushite & $\begin{array}{l}\text { Finely rough or aggregated rods, } \\
\text { cream to beige }\end{array}$ & $\begin{array}{l}\text { Concentric, radiating organization, } \\
\text { cream to beige }\end{array}$ \\
\hline \multirow[t]{2}{*}{ V } & $\mathrm{Va}$ & Cystine & Rough or grainy, yellowish & $\begin{array}{l}\text { Poorly organized, loose radiating } \\
\text { organization, yellowish }\end{array}$ \\
\hline & $\mathrm{Vb}$ & Cystine & Smooth, cream to pale yellowish & $\begin{array}{l}\text { Concentric in periphery, unorganized } \\
\text { core, cream to yellow }\end{array}$ \\
\hline \multirow[t]{3}{*}{ VI } & VIa & Proteins & Smooth, cream to pale brown & Unorganized, cream to pale brown \\
\hline & VIb & Proteins & $\begin{array}{l}\text { Rough and flaked off, dark brown to } \\
\text { black }\end{array}$ & $\begin{array}{l}\text { Crude and diffuse foliated structure, } \\
\text { dark brown to black }\end{array}$ \\
\hline & VIc & Proteins & Homogenous, smooth, dark brown & $\begin{array}{l}\text { Soft concentric dark-brown shell, unor- } \\
\text { ganized beige core }\end{array}$ \\
\hline \multicolumn{5}{|l|}{ Main mixed types } \\
\hline $\mathrm{Ia}+\mathrm{IIa}$ and $\mathrm{Ia}+\mathrm{IIb}$ & \multicolumn{4}{|c|}{ Whewellite + weddellite } \\
\hline $\mathrm{IIa}+\mathrm{IVa} 1$ and IIb + IVa1 & \multicolumn{4}{|c|}{ Weddellite + carbapatite } \\
\hline $\mathrm{Ia}+\mathrm{IIa}+\mathrm{IVa} 1$ & \multicolumn{4}{|c|}{ Whewellite + weddellite + carbapatite } \\
\hline
\end{tabular}

patients with recurrent stones. The patients who produced calcium oxalate stones had a mean of 3.5 stone episodes, while that number exceeded 7.5 for both brushite and cystine. This number is probably even higher for patients with uric acid stones, but it is difficult to evaluate with precision, as these patients often repeatedly form sand and/or 
Fig. 1 Photographs of the stone surface for the main morphological types of urinary calculi. Photographs a-d pure COM stones. Photograph e pure COD stone. Photograph f COD $(75 \%)+\operatorname{COM}(25 \%)$. Photographs $\mathbf{g}$ and $\mathbf{h}$ pure uric acid stones. Photograph $\mathbf{i}$ pure ammonium urate stone. Photograph $\mathbf{j}$ calcium phosphate stone made of a mixture of carbapatite $(80 \%)$ and of amorphous carbonated calcium phosphate (20\%). Photograph k nearly pure calcium phosphate stone: carbapatite $(95 \%)+$ COD (5\%). Photograph I carbapatite $(50 \%)+$ struvite $(40 \%)+$ amorphous carbonated calcium phosphate (10\%). Photograph m struvite $(90 \%)+$ carbapatite (10\%). Photograph $\mathbf{n}$ brushite $(90 \%)+\operatorname{COD}(5 \%)+$ carbapatite (5\%). Photograph o mixture of COM (70\%) and COD (30\%)
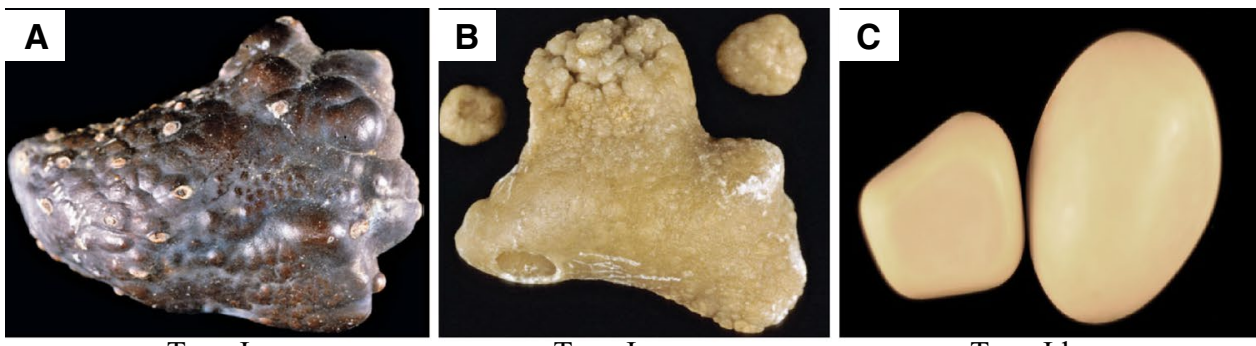

Type Ia

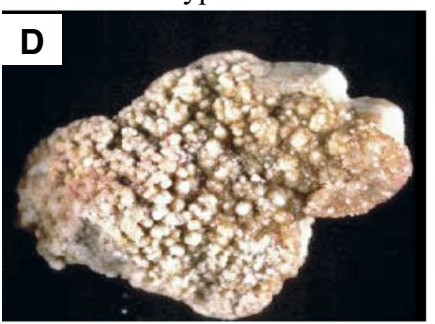

Type Ie

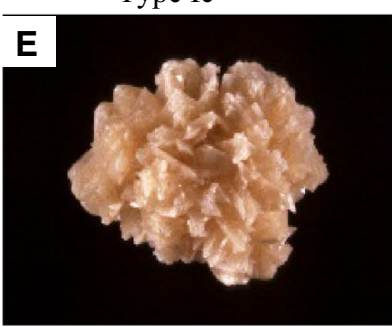

Type IIa

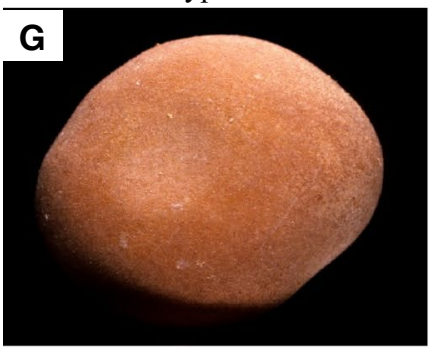

Type IIIa

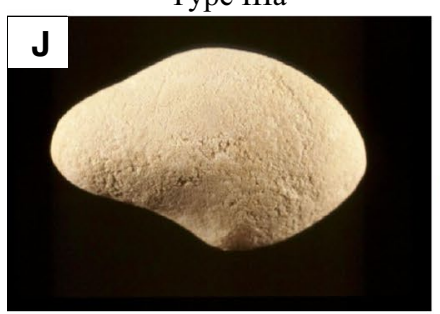

Type IVa1

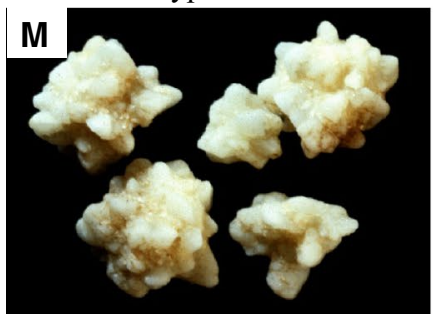

Type IVc

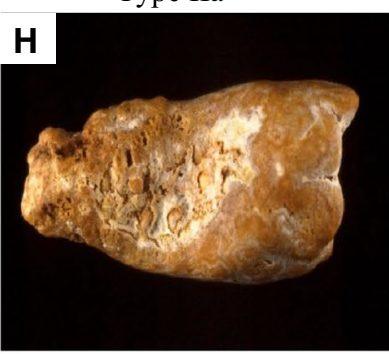

Type IIIb

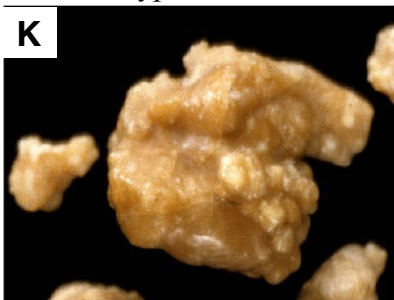

Type IVa2

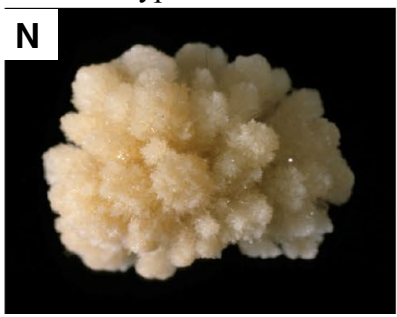

Type IVd
Type Id

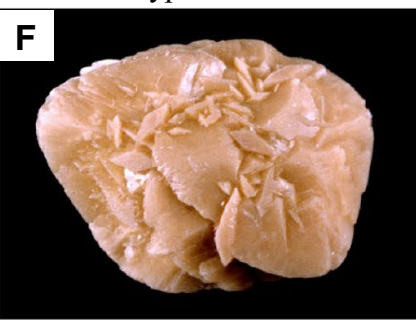

Type IIb

Type IIIc

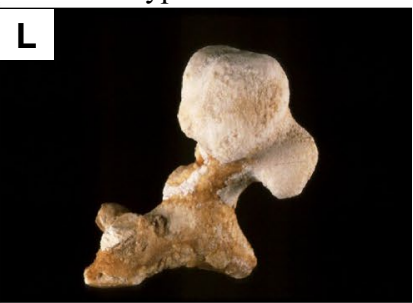

Type IVb

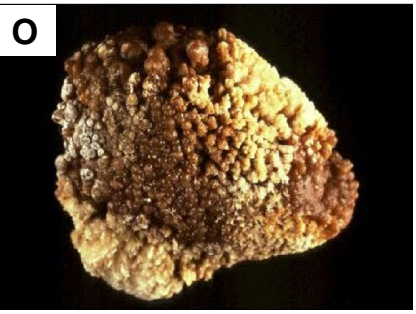

Mixed type Ia+IIa

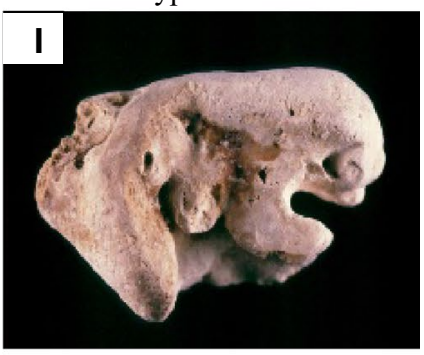

very small stones that are passed spontaneously with limited clinical symptoms. Moreover, in contrast to other crystalline species, stones composed of uric acid can be dissolved by urinary alkalization [17].

\section{Frequency of stone recurrence as a function of stone morphology}

The frequency of stone recurrence varied with morphological type (Table 4; Fig. 4). This was especially apparent in calcium oxalate stones where the recurrence rate varied among morphological types from 27 to $82 \%$, and in calcium phosphate stones, where the recurrence rate varied from 39 to $79 \%$ among the different morphological types. Overall, the recurrence rate of COM was relatively low (Table 3), but the morphological types Ie, and especially Ic, had higher rates of recurrence (Fig. 4). Thus, recognition of these morphological types of COM in a patient could alert the physician to the possibility of a greater chance of stone recurrence. 
Table 2 Mean age (years $\pm \mathrm{SD}$ ) at the first stone episode according to the stone composition

\begin{tabular}{|c|c|c|c|c|c|c|c|}
\hline \multirow[t]{2}{*}{ Main component } & \multicolumn{2}{|l|}{ Males } & \multicolumn{2}{|c|}{ Females } & \multicolumn{2}{|l|}{ All } & \multirow{2}{*}{$\begin{array}{l}p \text { value } \\
\mathrm{M} \text { vs } \mathrm{F}\end{array}$} \\
\hline & $N$ & Age & $N$ & Age & $N$ & Age & \\
\hline Dihydroxyadenine & 15 & $7.2 \pm 9.3$ & 6 & $29.0 \pm 17.3$ & 21 & $15.7 \pm 16.6$ & $<0.01$ \\
\hline Cystine & 43 & $26.5 \pm 20.1$ & 51 & $27.7 \pm 16.3$ & 94 & $27.1 \pm 18.2$ & NS \\
\hline Octacalcium phosphate pentahydrate & 16 & $25.6 \pm 18.4$ & 18 & $31.0 \pm 13.2$ & 34 & $28.6 \pm 15.9$ & NS \\
\hline Whitlockite & 21 & $25.1 \pm 19.2$ & 22 & $37.4 \pm 16.3$ & 43 & $31.4 \pm 18.4$ & $<0.05$ \\
\hline Ammonium hydrogen urate & 48 & $25.4 \pm 27.1$ & 35 & $43.7 \pm 19.8$ & 83 & $33.1 \pm 26.1$ & $<0.001$ \\
\hline Weddellite (COD)* & 3440 & $41.0 \pm 14.0$ & 1039 & $39.7 \pm 16.1$ & 4469 & $40.7 \pm 14.6$ & $<0.05$ \\
\hline Brushite & 162 & $42.8 \pm 16.8$ & 59 & $38.2 \pm 16.2$ & 221 & $41.6 \pm 16.9$ & NS \\
\hline Carbapatite & 1064 & $39.4 \pm 22.9$ & 1702 & $43.1 \pm 16.9$ & 2766 & $41.7 \pm 19.6$ & $<0.001$ \\
\hline Amorphous carbonated calcium phosphate & 17 & $37.7 \pm 30.1$ & 29 & $44.4 \pm 25.1$ & 46 & $41.9 \pm 27.1$ & NS \\
\hline Struvite & 157 & $44.2 \pm 26.5$ & 205 & $47.2 \pm 21.3$ & 362 & $45.9 \pm 23.7$ & NS \\
\hline Whewellite $(\mathrm{COM})^{*}$ & 7890 & $48.8 \pm 14.4$ & 3383 & $47,4 \pm 16.5$ & 11,273 & $48.4 \pm 15.1$ & $<0.01$ \\
\hline Uric acid dihydrate & 192 & $58.3 \pm 12.9$ & 40 & $62.9 \pm 14.0$ & 232 & $59.1 \pm 13.3$ & NS \\
\hline Uric acid anhydrous & 1080 & $62.8 \pm 14.6$ & 366 & $61.8 \pm 15.1$ & 1446 & $62.5 \pm 14.9$ & NS \\
\hline
\end{tabular}

$* \mathrm{COM}=$ calcium oxalate monohydrate $-\mathrm{COD}=$ calcium oxalate dihydrate
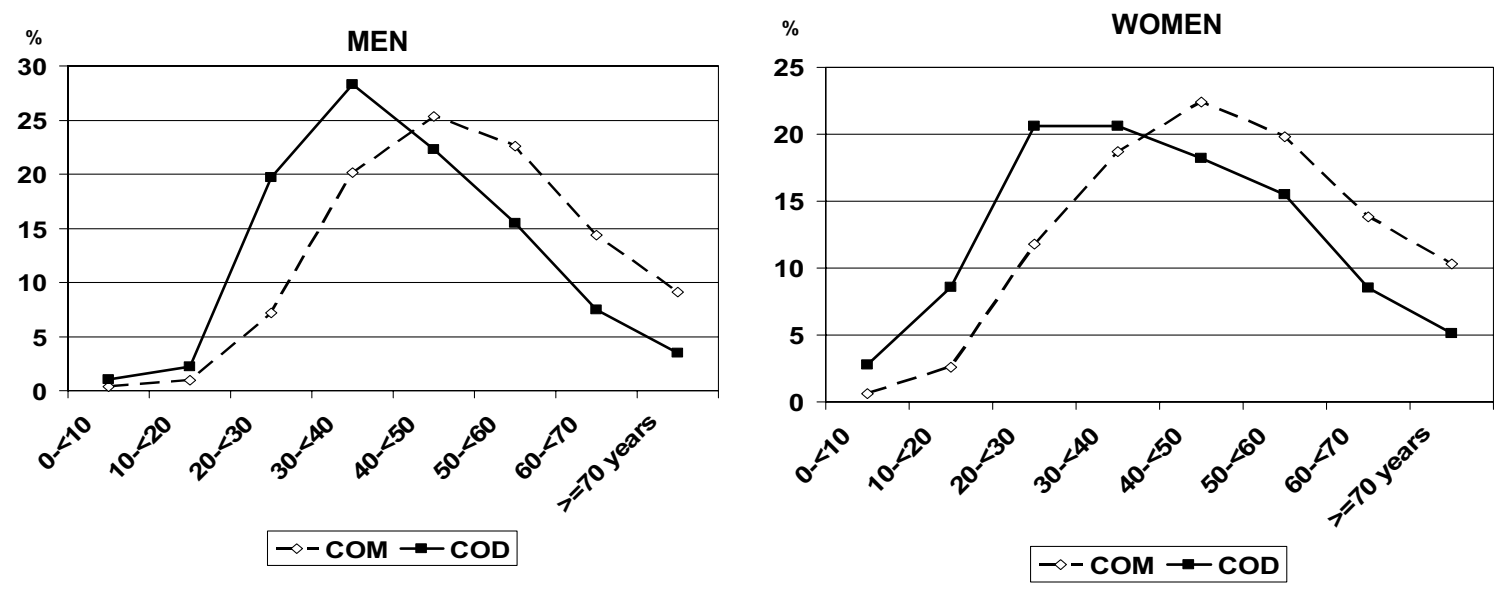

Fig. 2 Age distribution of patients at the onset of COM or COD stone disease in both genders

For stones containing mainly COD (type II), the percentage of stones that were recurrent was generally not different from the mean of all stones, except for type Ia + IIb (mixture of COM and COD) which were less recurrent and type IIa + IVa1 (COD and carbapatite) stones which were significantly more recurrent.

Regarding stones composed primarily of forms of calcium phosphate, types IVa1 and IVa2 (both types of carbapatite) were very different, the latter being significantly more recurrent than the mean of all stones from men and women, suggesting the possibility of more active metabolic processes driving this morphological form. Type IVd (brushite) was also significantly more recurrent in both sexes, consistent with the high recurrence rate of this stone type reported in American studies [18-20].
Stones composed of uric acid of type IIIb (not type IIIa, often related to stasis) or cystine were significantly more recurrent than the mean for all stones, consistent with these stones resulting from metabolic processes more active than those that drive the formation of common calcium stones.

\section{Influence of Randall's plaque (RP)}

As seen in Table 5, calcium oxalate stones developed from RP actually seem to exhibit a slight tendency to be more recurrent than stones formed by other mechanisms $(p=0.02)$, with a significant difference according to the gender of patients. In men, $41 \%$ of stones with an RP were recurrent by comparison with $38.6 \%$ of stones without any $\operatorname{RP}(p<0.01)$. No significant difference was found in stones 


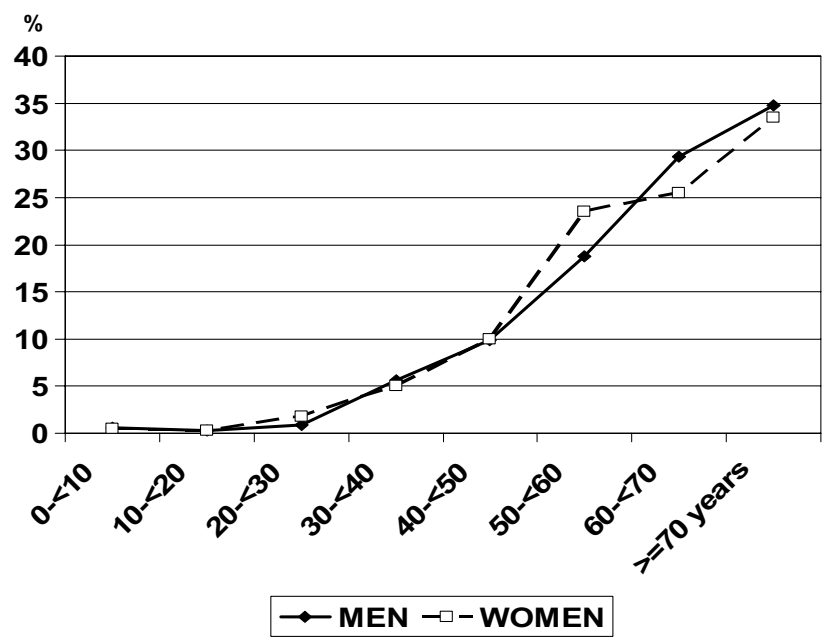

Fig. 3 Age distribution of patients at the onset of uric acid stones in men and women

from women. However, differences exist regarding the stone type. For example, COM stones of type Ia developed from an RP appear significantly more recurrent than COM stones of type Ia without RP in men (38.1 vs $33.5 \%, p<0.001)$ with only a trend in women (32.1 vs $28 \%, p=0.07)$. In addition, stones of mixed types I + II and II + I are significantly more recurrent than type Ia stones in men in both groups of stones with and without RP and in women in the group of stones without RP.

\section{Discussion}

Stone disease is a very common finding in industrialized countries and is constantly increasing as revealed by epidemiological studies [21-23]. In most cases, it is a consequence of dietary imbalance and/or chronically insufficient water intake. In general, the correction of these factors should prevent stone recurrence. However, among stone diseases, metabolic forms exist that expose the patient to multiple recurrences of calculi with the possible consequence of altering the kidney function and, sometimes, inducing end-stage renal failure. These may result from inherited or acquired pathologies, the diagnosis of which is of crucial importance to treating them and reducing the risk of stone recurrence and crystallization in the kidney. Stone analysis at the first episode is one method for the early detection of stone diseases which are prone to recur. As shown in the present study, there are great differences in terms of stone recurrence risk according to both stone composition and morphology.

\section{Onset of stones}

The mean age at the onset of the disease, as revealed by a stone episode, varied in relation to the stone composition. The earliest component found was dihydroxyadenine, which corresponds to an adenine phosphoribosyltransferase deficiency, an inherited autosomal disease
Table 3 Frequency of stone recurrence according to the stone composition

\begin{tabular}{|c|c|c|c|c|c|c|}
\hline \multirow[t]{2}{*}{ Component } & \multicolumn{2}{|l|}{ Males } & \multicolumn{2}{|c|}{ Females } & \multicolumn{2}{|l|}{ Total } \\
\hline & $N$ & $\%$ & $N$ & $\%$ & $N$ & $\%$ \\
\hline $\mathrm{ACCP}^{(1)}$ & 8 & 32.0 & 13 & 30.2 & 21 & 30.9 \\
\hline Whitlockite & 10 & 32.3 & 14 & 38.9 & 24 & 35.8 \\
\hline Whewellite (COM) & 5241 & $39.5 * * *, \mathrm{e}$ & 1768 & $34.1^{\mathrm{e}}$ & 7013 & $38.0^{\mathrm{e}}$ \\
\hline Struvite & 143 & $47.0 * *$ & 121 & 36.7 & 264 & 41.6 \\
\hline Presence of struvite & 492 & $44.9 * * *$ & 526 & 36.5 & 1018 & 40.1 \\
\hline Ammonium Urate & 28 & 36.8 & 32 & 47.1 & 60 & 41.7 \\
\hline Weddellite (COD) & 2883 & $45.2 * * *$ & 625 & 37.2 & 3508 & $43.5^{\mathrm{a}}$ \\
\hline Carbapatite & 1022 & $48.8^{* * *, \mathrm{e}}$ & 1143 & 39.9 & 2165 & $43.6^{\mathrm{a}}$ \\
\hline Uric acid anhydrous & 1193 & $52.1^{*, \mathrm{e}}$ & 329 & $46.8^{\mathrm{c}}$ & 1522 & $50.9^{\mathrm{e}}$ \\
\hline Uric acid dihydrate & 198 & $50.6^{\mathrm{a}}$ & 50 & $55.6^{\mathrm{b}}$ & 248 & $51.6^{\mathrm{c}}$ \\
\hline Octacalcium phosphate & 28 & $63.6^{*, a}$ & 15 & 45.5 & 43 & 55.8 \\
\hline Brushite & 479 & $75.7^{\mathrm{e}}$ & 143 & $70.8^{\mathrm{e}}$ & 622 & $74.5^{\mathrm{e}}$ \\
\hline Cystine & 378 & $90.9^{\mathrm{e}}$ & 293 & $86.7^{\mathrm{e}}$ & 671 & $89.0^{\mathrm{e}}$ \\
\hline Dihydroxyadenine & 19 & $95.0^{\mathrm{d}}$ & 7 & $100^{\mathrm{b}}$ & 26 & $96.3^{\mathrm{e}}$ \\
\hline All stones & 11,702 & $44.4 * * *$ & 4634 & 38.9 & 16,341 & 42.7 \\
\hline
\end{tabular}


Table 4 Frequency of stone recurrence according to the morphological type of the stone

\begin{tabular}{|c|c|c|c|c|c|c|}
\hline \multirow[t]{2}{*}{ Morphological type ${ }^{(1)}$} & \multicolumn{2}{|l|}{ Males } & \multicolumn{2}{|c|}{ Females } & \multicolumn{2}{|l|}{ Total } \\
\hline & $N$ & $\%$ & $N$ & $\%$ & $N$ & $\%$ \\
\hline \multicolumn{7}{|l|}{ Calcium oxalates } \\
\hline Ia & 1735 & $35.9 * * *, \mathrm{e}$ & 499 & $29.8^{\mathrm{d}}$ & 2234 & $34.3^{\mathrm{e}}$ \\
\hline $\mathrm{Ib}$ & 58 & $26.1^{\mathrm{c}}$ & 25 & 30.9 & 83 & $27.4^{\mathrm{d}}$ \\
\hline Ic & 29 & $85.3^{\mathrm{e}}$ & 13 & $76.5^{\mathrm{b}}$ & 42 & $82.4^{\mathrm{e}}$ \\
\hline Id & 66 & 40.0 & 43 & 46.2 & 109 & 42.3 \\
\hline $\mathrm{Ie}$ & 44 & 54.3 & 26 & 48.2 & 70 & 51.9 \\
\hline $\mathrm{Ia}+\mathrm{IIa}$ & 424 & 41.7 & 147 & 38.6 & 571 & 40.8 \\
\hline $\mathrm{Ia}+\mathrm{IIb}$ & 1051 & $39.5 * * \mathrm{e}$ & 306 & $32.1^{\mathrm{b}}$ & 1359 & $37.6^{\mathrm{e}}$ \\
\hline $\mathrm{IIb}+\mathrm{Ia}$ & 1433 & $44.4 * *$ & 380 & 38.7 & 1813 & 43.1 \\
\hline IIa & 773 & $44.6^{* *}$ & 161 & 37.6 & 934 & 43.2 \\
\hline IIb & 400 & $39.1^{\mathrm{a}}$ & 86 & 25.4 & 486 & 38.4 \\
\hline IIa + IVa1 & 959 & $48.5 * *, \mathrm{~b}$ & 286 & 40.8 & 1245 & $46.5^{\mathrm{c}}$ \\
\hline $\mathrm{IIb}+\mathrm{IVa} 1$ & 213 & 39.1 & 99 & 40.4 & 312 & 39.5 \\
\hline $\mathrm{Ia}+\mathrm{IIa}+\mathrm{IVa} 1$ & 682 & $46.4 * *$ & 326 & 36.8 & 1008 & 42.8 \\
\hline \multicolumn{7}{|l|}{ Calcium phosphates } \\
\hline IVa1 (w/o struvite) & 110 & $47.8^{* *, a}$ & 125 & 38.0 & 235 & 42.0 \\
\hline IVa2 & 26 & $70.3^{\mathrm{a}}$ & 53 & $84.1^{\mathrm{e}}$ & 79 & $79.0^{\mathrm{e}}$ \\
\hline $\mathrm{IVb}$ & 221 & $48.3 * * *$ & 335 & $35.2^{\mathrm{a}}$ & 556 & $39.4^{\mathrm{b}}$ \\
\hline IVd & 229 & $73.6^{\mathrm{e}}$ & 73 & $68.9^{\mathrm{e}}$ & 302 & $72.4^{\mathrm{e}}$ \\
\hline \multicolumn{7}{|c|}{ Struvite (magnesium ammonium phosphate hexahydrate) } \\
\hline $\mathrm{IVc}$ & 29 & 53.7 & 17 & 32.7 & 46 & 43.4 \\
\hline \multicolumn{7}{|l|}{ Uric acids } \\
\hline IIIa & 186 & 45.7 & 39 & $50.7^{\mathrm{a}}$ & 225 & 46.5 \\
\hline IIIb & 840 & $53.2^{* *, \mathrm{e}}$ & 230 & $47.2^{\mathrm{b}}$ & 1070 & $51.8^{\mathrm{e}}$ \\
\hline \multicolumn{7}{|l|}{ Cystine } \\
\hline $\mathrm{Va}$ & 312 & 90.7 & 233 & $84.7^{\mathrm{e}}$ & 545 & $88.1^{\mathrm{e}}$ \\
\hline $\mathrm{Vb}$ & 20 & 100 & 7 & $100^{\mathrm{b}}$ & 27 & $100^{\mathrm{e}}$ \\
\hline
\end{tabular}

often inducing end-stage renal failure when undiagnosed [24-27]. Unexpectedly, there was a strong difference in the onset of the disease according to gender, males being prone to develop stones earlier than females. Perhaps a bias exists due to the small number of cases. Coming next were cystine stones which, despite the fact that they result from a congenital defect in tubular transport, in contrast to dihydroxyadenine stones, are known to make their appearance in the second or third decade of life [28, 29]. Indeed, the data here suggest that some cystine stone formers do not present their first stone until the seventh decade of life. The next earliest component was octacalcium phosphate, an instable form of apatite able to convert to it in some months. The next component was whitlockite, an infrequently found form of calcium magnesium phosphate, which, in our experience, is essentially a marker of infection [30].
Ammonium hydrogen urate stones were found significantly earlier in men than in women. A possible explanation is related to stones induced by urea-splitting bacteria. Such stones contain ammonium salts such as struvite and/or ammonium urate. They are especially frequent in very young boys (at the time where uricosuria is still elevated) and more later in life for women.

COD, found as the first stone at the mean age of 40 years, is a rather calcium-dependent form of calcium oxalate stone, mainly observed in hypercalciuric states [12, 13, 31]. Four forms of phosphate stone, including amorphous carbonated calcium phosphate, carbapatite, brushite and struvite, also appeared at an average first age in the forties. Interestingly, the average age of onset of the most common form of stone, $\mathrm{COM}$, was later than all of these, at 48 years of age. Of note, in Japan, Koide et al. reported in the eighties that patients who form COD stones are different from those who form 
Fig. 4 Recurrence of stones by morphology. Type Ia and type Ic stones are made of pure or nearly pure calcium oxalate monohydrate, which accounts for more than $95 \%$ of the stone mass. Type IVa1 and type IVa2 stones are made of nearly pure calcium orthophosphates (mainly carbapatite), which account for more than $90 \%$ of the stone mass. *Significantly different from mean of all stones, $p<0.01$, with mean shown by horizontal line

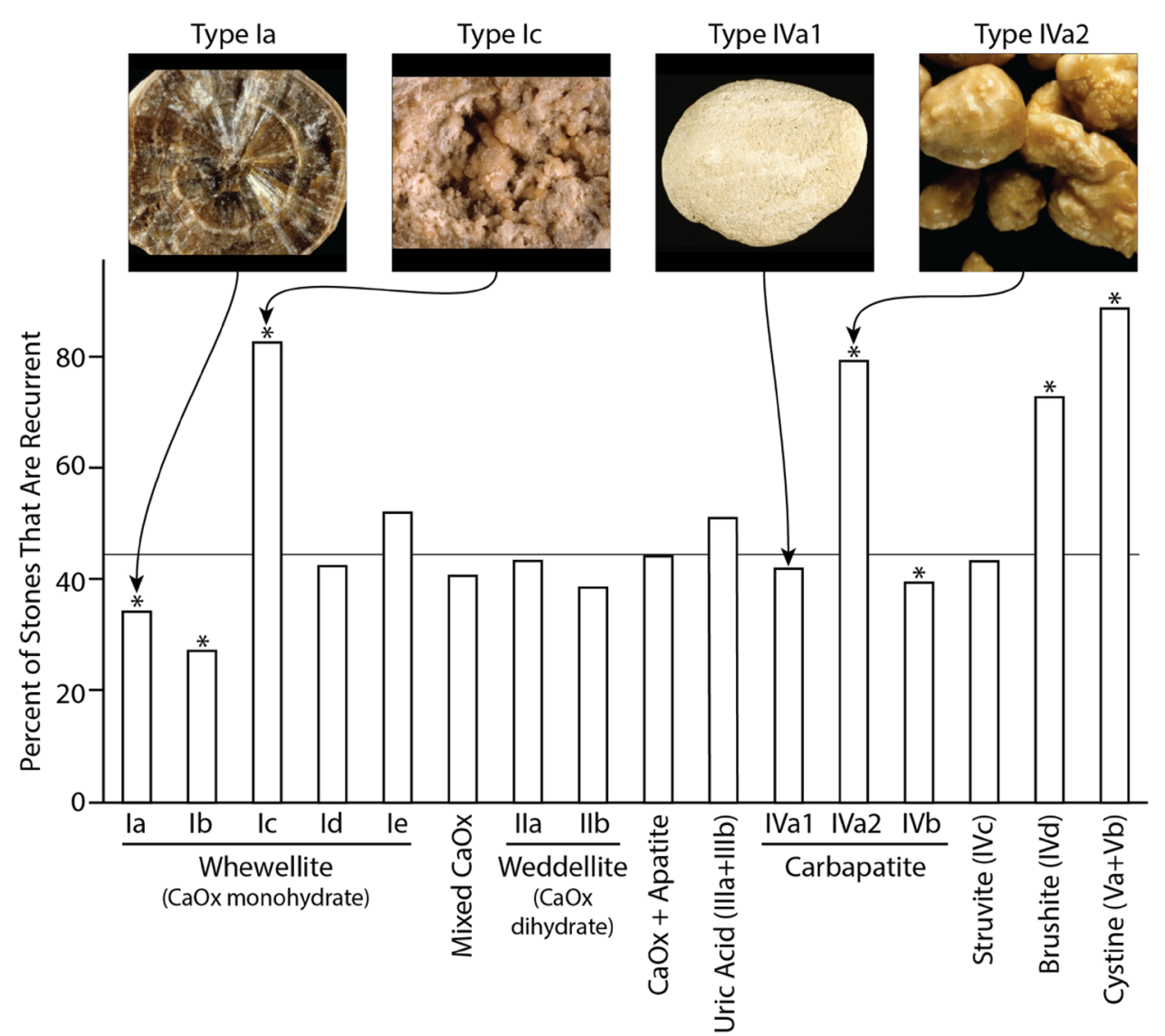

Table 5 Comparison between umbilicated stones or not

\begin{tabular}{|c|c|c|c|c|c|c|}
\hline \multirow[t]{2}{*}{ Morphological type } & \multicolumn{2}{|l|}{ Males } & \multicolumn{2}{|l|}{ Females } & \multicolumn{2}{|l|}{ Total } \\
\hline & First stone & Recurrence & First stone & Recurrence & First stone & Recurrence \\
\hline \multicolumn{7}{|c|}{ Umbilicated stones with Randall's plaque } \\
\hline Type Ia alone & 1549 & $954(38.1)^{* * *, \mathrm{~b}, \mathrm{xx}}$ & 501 & $237(32.1)^{\mathrm{x}}$ & 2050 & $1191(36.7)^{* * * *}$ \\
\hline Mixed types I+ II & 869 & $650(42.8)^{* *, b, \dagger \dagger}$ & 332 & $171(34.0)$ & 1201 & $821(40.6)^{\dagger \dagger}$ \\
\hline Mixed types II + I & 360 & $328(47.7)^{\mathrm{c}, \dagger+\dagger \dagger}$ & 108 & $57(34.6)$ & 468 & $385(45.1)^{\dagger \dagger \dagger \dagger}$ \\
\hline Total & 2778 & $1932(41.0)^{* *, \mathrm{~d}, \mathrm{xx}}$ & 941 & $465(33.1)^{\mathrm{xx}}$ & 3719 & $2397(39.2)^{*, \mathrm{xx}}$ \\
\hline \multicolumn{7}{|c|}{ Stones without any umbilication nor Randall's plaque } \\
\hline Type Ia alone & 1551 & $781(33.5)^{\mathrm{b}}$ & 674 & $262(28.0)^{\mathrm{xx}}$ & 2225 & $1043(31.9)^{\mathrm{xx}}$ \\
\hline $\mathrm{I}+\mathrm{II}$ & 1332 & $825(38.2)^{\mathrm{a}, \mathrm{xx}, \dagger \dagger \dagger}$ & 548 & $282(34.0)^{\mathrm{x}, \dagger \dagger}$ & 1880 & $1107(37.1)^{\mathrm{xx}, \dagger+\dagger \dagger}$ \\
\hline $\mathrm{II}+\mathrm{I}$ & 1433 & $1105(43.5)^{\mathrm{a}, \uparrow \dagger \dagger}$ & 493 & $323(39.6)^{\dagger \dagger \dagger \dagger}$ & 1926 & $1428(42.6)^{\dagger \dagger \dagger \dagger}$ \\
\hline Total & 4316 & $2711(38.6)^{\mathrm{c}, \mathrm{xx}}$ & 1715 & $867(33.6)^{\mathrm{xx}}$ & 6031 & $3578(37.2)^{\mathrm{xx}}$ \\
\hline
\end{tabular}

Stones of mixed types I+ II include stones with various subtypes where COM was the main crystalline phase of calcium oxalate. By contrast, stones of mixed types II + I include stones with various subtypes where COD was the main crystalline phase of calcium oxalate. As shown in the table, the recurrence rate is not the same according to the main crystalline phase of calcium oxalate: when COD is the main crystalline phase, the stones are commonly more recurrent by comparison with type Ia stones used as a reference

${ }^{*} p=0.02 ; * * p<0.01 ; * * * p<0.001 ; * * * * p<0.0001$ vs non-umbilicated stones

${ }^{\dagger} p<0.05 ;{ }^{\dagger \dagger} p<0.01 ;{ }^{\dagger \dagger} p<0.001 ;{ }^{\dagger \dagger} p<0.0001$ vs type Ia stones for a given gender

${ }^{\mathrm{a}} p<0.05 ;{ }^{\mathrm{b}} p<0.01 ;{ }^{\mathrm{c}} p<0.001 ;{ }^{\mathrm{d}} p<0.0001$ vs females

${ }^{\mathrm{x}} p<0.01 ;{ }^{\mathrm{xx}} p<0.0001$ vs mean occurrence of stone recurrence for a given gender 
COM stones and that COD stones were observed earlier than COM stones in Japanese patients [32]. Finally, the age of first occurrence of uric acid stones was much later, at about 60 years of age, probably related to the increased occurrence at older ages of overweight, metabolic syndrome, and type 2 diabetes [33, 34].

\section{Stone recurrence}

A stone recurrence rate around $50 \%$ is commonly accepted in the literature, both in children and adults [35, 36]. However, no data are reported regarding crystalline phases of the stones. Among the stone mineral types seen with the lowest percentages of recurrence (Table 3 ), three were phosphate stones composed of minerals that have been shown to be related to urinary tract infection (whitlockite, amorphous carbonated calcium phosphate, and struvite) [30]. These results seem reasonable because stones occurring due to infection are not likely to recur if the infection is successfully treated. Within the range of recurrence frequency of infection stones, however, are also stones composed of COM, for which the underlying cause for stone formation is generally a hyperoxaluria of moderate degree [12, 37, 38]. Thus, it is apparent that COM stones are less likely to be recurrent than are other calcium stones whose origins are also metabolic, but for which the endogenous biochemical abnormalities are more marked. It is also interesting to note that the percentage of recurrent COM stones is less than the mean percentage for all recurrent stones, for both men and women.

If we consider that physicians propose for preventing recurrence of all urinary stones adequate dietary advices or medical treatment according to the stone composition (calcium stone, uric acid stone, cystine stone, struvite stone...), it is unlikely that stone recurrence might be a consequence of an inappropriate medical care. Obviously, we cannot exclude that patients were not compliant with physician recommendations. However, there is no evidence that such default of compliance may depend on stone type. Thus, intrinsic characteristics of crystalline phases or of stone morphology appear highly suggestive for different courses of stone disease.

Among the four compositions that are least recurrent, struvite is obviously special. Although in women the percentage of recurrent stones composed of struvite was slightly less than the mean for all stones, struvite stones were considerably more recurrent in men. This difference may occur for a number of reasons. First, anatomical and disease conditions could make the formation of struvite stones more favorable in men, especially prostatic hypertrophy, which often causes incomplete emptying of the urinary bladder. However, in our experience, only one-third of bladder struvite stones associated with prostate hypertrophy were recurrent. Another reason for the higher incidence of recurrent struvite stones in men could be that infection is less expected in men, and thus not recognized and promptly treated as often as it is in women. In any case, when one examines the epidemiologic changes in stones in France over the past 30 years, one can see that the frequency of infection stones has fallen dramatically for women-3.5-fold-while that for men has dropped by only $20 \%$ [39]. Of note, recent epidemiological data suggest that struvite stones could be more frequent in recent decades by comparison to previous reports, especially in men [40].

Ammonium urate was found to be slightly less recurrent by comparison to the whole series. It was a more recurrent component in women than in men. Although it is always found with hyperuricosuria, other factors are necessary to its formation and it can appear in the context of different pathologies (anorexia and laxative abuse, infection with urea-splitting organisms, poor animal protein diet and chronic diarrhea, etc. [41, 42]).

Among the more recurrent compositions, octacalcium phosphate and the two forms of uric acid are at levels just slightly above the average percentage for all stones. These stones include a species that is at least suspected of being calcium-dependent (octacalcium phosphate [30, 43]), and two species (uric acid, both anhydrous and dihydrate) that are frequently associated with metabolic syndrome and diabetes [33, 34, 44].

The three most recurrent species were found to be dihydroxyadenine, cystine and, surprisingly, brushite. The first two crystalline species are due to well-defined inherited disorders. In contrast, brushite in stones is not recognized as a marker of any genetically linked pathology; yet the rapid growth of brushite stones leads to recurrence rates similar to those of stones formed as the result of genetic disorders, with $75 \%$ of brushite stones coming from patients who have already had at least one stone episode. Moreover, patients with brushite stones very often have had repeated stone episodes and frequently are found to have multiple stones with each incidence and a higher number of urological procedures [18-20]. Brushite stones are also classed, along with those of cystine, as the stones most difficult to break [45]. These results suggest the need for more sophisticated studies of the metabolic disorders present in the patients who produce brushite stones. Indeed, the incidence of brushite stones has increased considerably over the past years, from $0.8 \%$ of all stones in 1980 to $2.2 \%$ today in France [46] and from 1.7 to $4.1 \%$ in the United States [47].

If one compares the recurrence rate of stones between men and women, one can state that all stone types recur more frequently in men, with the exception of ammonium urate, uric acid dihydrate, brushite, and the stones of an obviously genetic origin (cystine and dihydroxyadenine) for which one observes no significant difference in recurrence rates between the sexes. These data suggest a role 
for environmental factors, particularly nutritional differences, for those stone types that are more recurrent in men; conversely, endogenous metabolic disorders, congenital or acquired, for which stone occurrence is linked to the nature of the metabolic abnormality rather than to environmental factors, seem to be more important for those stone types for which recurrence does not differ between the sexes.

\section{Relationship between stone recurrence and morphology}

A unique aspect of the present study is the examination of relationships between stone recurrence and morphologies of stones, which can differ even within the same compositional class. For example, even though the overall recurrence rate of COM stones was relatively low, the recurrence rates of some morphologies of COM were significantly higher (Fig. 4). We are aware of the relatively small number of stones regarding some morphological types. However, despite this limitation, the significant differences between stones types for the same crystalline species may alert us on special risk factors related to such stone types. Thus, recognition of more recurrent morphologies of COM in a patient could be of benefit in diagnosis and treatment.

Among stones composed mainly of COD (type II), the sub-type IIb was found to be significantly less recurrent than were the sub-types IIa or IIa + IVa1, the latter of which was more recurrent than the mean for all stones, whether just for men or for the entire series. However, these recurrence rates among morphological forms of COD stones-in contrast to what was observed for COM-are relatively small, perhaps reflecting the overall influence of hypercalciuria in the formation of this mineral type [11-13].

Among stones composed mainly of carbapatite, the morphology of type IVa2 (stones with an irregular but shiny surface, with subsurface cracks visible beneath the translucent surface coat) correlated with a higher incidence of recurrence than for other carbapatite stones. In our experience, these stones are associated with all conditions of distal tubular acidosis, i.e., Sjögren syndrome, inherited renal tubular acidosis, medullary sponge kidney [48]. In contrast, carbapatite morphology IVb (heterogeneous surface composed of incomplete layers with varying texture and color, including bumpy/rough regions) was less recurrent, especially in women. This morphology is frequently associated with infection [9], so the difference in its recurrence between men and women could be related to a poorer detection and/ or a less effective medical surveillance for men in this context than for women.

At last, we found differences in the occurrence rate according to the presence or not of a RP. It was shown since more than twenty years that RP is now the main factor involved in initiating calcium oxalate stone formation
[49-51]. Based on visual inspection of papillae thanks to ureteroscopy, it was reported that most calcium stone formers exhibit multiple papillary calcifications [52]. On the other hand, it was reported a higher occurrence of kidney stones related to the papillary coverage by Randall's plaque [53]. Thus, it would be expected that stones developed from RP should be especially at risk to recur. As shown in Table 5, the difference between stones developed from $\mathrm{RP}$ and similar stones developed without RP is not so high. However, when stone types are taken into account, calcium oxalate stones made of a combination of COM and COD (mixed types $\mathrm{I}+\mathrm{II}$ and $\mathrm{II}+\mathrm{I}$ ) are significantly more recurrent than stones exclusively made of COM, suggesting that metabolic differences could exist between patients producing these different types of stones. Further studies are needed to confirm such hypothesis.

In conclusion, recurrence of urolithiasis is quite variable, being correlated with not only the crystalline composition of the stones, but also with morphological types and certain other structural characteristics. Among calcium oxalate stones, COD stones recur considerably more often than do stones composed of COM. Among calcium phosphate stones, octacalcium phosphate and, above all, brushite stones are more recurrent than other phosphate stone compositions. Brushite stones are especially notable in this regard, not only for their high degree of recurrence, but also because they tend to recur as multiple stones and because the underlying causes of brushite stone formation have not yet been clearly established. Our results also show that the morphology of the stones is important. Thus, it would seem appropriate for clinical work not to limit stone analysis to stone composition only, but also to take into consideration the morphology of the stone, as this can help in diagnosis and in pinpointing the factors that are causative for stone formation, so that better measures for prevention of stone recurrence can be prescribed for each patient.

\section{Compliance with ethical standards}

Conflict of interest The authors declare no conflict of interest.

Ethical approval All the specimens of our database were de-identified. All procedures performed in the study were in accordance with the ethical standards of the institutional research committee.

Informed consent Informed consent was obtained from all individual participants.

\section{References}

1. Ljunghall S, Lithell H, Skarfors E (1987) Prevalence of renal stones in 60-year-old men. A 10-year follow-up study of a health survey. Br J Urol 60:10-13 
2. Ahlstrand C, Tiselius HG (1990) Recurrences during a 10-year follow-up after first renal stone episode. Urol Res 18:397-399

3. Ulmann A, Clavel J, Destree D, Dubois C, Mombet A, Brisset JM (1991) Histoire naturelle de la lithiase rénale calcique: données obtenues à partir d'une cohorte de 667 malades. Presse Med 20:499-502

4. Chow GK, Streem SB (1998) Contemporary urological intervention for cystinuric patients: immediate and long-term impact and implications. J Urol 160:341-344 (discussion 344-345)

5. Millman S, Strauss AL, Parks JH, Coe FL (1982) Pathogenesis and clinical course of mixed calcium oxalate and uric acid nephrolithiasis. Kidney Int 22:366-370

6. Koide T, Itatani H, Yoshioka T et al (1982) Clinical manifestations of calcium oxalate monohydrate and dihydraté urolithiasis. J Urol 127:1067-1069

7. Ohman S, Larsson L, Tiselius HG (1992) Clinical significance of phosphate in calcium oxalate renal stones. Ann Clin Biochem 29:59-63

8. Daudon M, Protat MF, Réveillaud RJ (1978) Analysis of calculi by infrared spectrophotometry. Advantages and limits of the method. Ann Biol Clin 36:475-489

9. Daudon M, Bader CA, Jungers P (1993) Urinary calculi: review of classification methods and correlations with etiology. Scanning Microsc 7:1081-1106

10. Daudon M, Jungers P (2012) Stone composition and morphology: a window on etiology. In: Talati JJ, Tiselius HG, Albala DM, Ye Z (eds) Urolithiasis: basic science and clinical practice. Springer, London, pp 113-140

11. Daudon M, Donsimoni R, Hennequin C, Fellahi S, Le Moël G, Paris M et al (1995) Sex and age-related composition of 10617 calculi analyzed by infrared-spectroscopy. Urol Res 23:319-326

12. Daudon M, Réveillaud RJ (1984) Whewellite and weddellite: toward a different etiopathogenesis. The significance of morphological typing of calculi. Néphrologie 5:195-201

13. Asplin JR, Lingeman JE, Kahnoski R, Mardis H, Parks JH, Coe. FL (1998) Metabolic urinary correlates of calcium oxalate dihydrate in renal stones. J Urol 159: 664-668

14. Parent X, Boess G, Brignon P (1999) Calcium oxalate stones. Relationship between biochemical risk factors and crystalline phase of the stone. Prog Urol 9:1051-1056

15. Mandel NS, Mandel GS (1989) Urinary tract stone disease in the United States veteran population. II. Geographical analysis of variations in composition. J Urol 142:1516-1521

16. Brien G, Schubert G, Bick C (1982) 10,000 analyses of urinary calculi using $\mathrm{X}$-ray diffraction and polarizing microscopy. Eur Urol 8:251-256

17. Moran ME (2003) Uric acid stone disease. Front in Biosci 8:1339-1355

18. Klee LW, Brito CG, Lingeman JE (1991) The clinical implications of brushite calculi. J Urol 145:715-718

19. Parks JH, Worcester EM, Coe FL, Evan AP, Lingeman JE (2004) Clinical implications of abundant calcium phosphate in routinely analyzed kidney stones. Kidney Int 66:777-785

20. Evan AP, Lingeman JE, Coe FL et al (2005) Crystal-associated nephropathy in patients with brushite nephrolithiasis. Kidney Int 67:576-591

21. Stamatelou KK, Francis ME, Jones CA, Nyberg LM Jr, Curhan GC (2003) Time trends in reported prevalence of kidney stones in the United States: 1976-1994. Kidney Int 63:1817-1823

22. Hesse A, Brandle E, Wilbert D, Kohrmann KU, Alken P (2003) Study on the prevalence and incidence of urolithiasis in Germany comparing the years 1979 vs. 2000. Eur Urol 44:709-713

23. Trinchieri A, Coppi F, Montanari E, Del Nero A, Zanetti G, Pisani E (2000) Increase in the prevalence of symptomatic upper urinary tract stones during the last ten years. Eur Urol $37: 23-25$
24. Gagné ER, Deland E, Daudon M, Noel L-H, Nawar T (1994) Chronic renal failure secondary to 2,8-dihydroxyadenine deposition: the first report of recurrence in a kidney transplant. Am J Kidney Dis 24:104-107

25. de Jong DJ, Assmann KJ, De Abreu RA et al (1996) 2,8-Dihydroxyadenine stone formation in a renal transplant recipient due to adenine phosphoribosyltransferase deficiency. J Urol 156:1754-1755

26. Glicklich D, Gruber HE, Matas AJ et al (1988) 2,8-Dihydroxyadenine urolithiasis: report of a case first diagnosed after renal transplant. Q J Med 68:785-793

27. Stratta P, Fogazzi GB, Canavese C et al (2010) Decreased kidney function and crystal deposition in the tubules after kidney transplant. Am J Kidney Dis 56:585-590

28. Singer A, Das A (1989) Cystinuria: a review of the pathophysiology and management. J Urol 142:669-673

29. Prot-Bertoye C, Lebbah S, Daudon M et al (2015) CKD and its risk factors among patients with cystinuria. Clin J Am Soc Nephrol 10:842-851

30. Maurice-Estepa L, Levillain P, Lacour B, Daudon M (1999) Crystalline phase differentiation in urinary calcium phosphate and magnesium phosphate calculi. Scand J Urol Nephrol 33:299-305

31. Daudon M, Jungers P (2004) Clinical value of crystalluria and quantitative morphoconstitutional analysis of urinary calculi. Nephron Physiol 98:31-36

32. Koide T, Itatani H, Yoshioka T et al (1982) Clinical manifestations of calcium oxalate monohydrate and dihydrate urolithiasis. J Urol 127:1067-1069

33. Daudon M, Lacour B, Jungers P (2006) Influence of body size on urinary stone composition in men and women. Urol Res 34:193-199

34. Daudon M, Traxer O, Conort P, Lacour B, Jungers P (2006) Type 2 diabetes increases the risk for uric acid stones. J Am Soc Nephrol 17:2026-2033

35. Tasian GE, Kabarriti AE, Kalmus A, Furth SL (2017) Kidney stone recurrence among children and adolescents. J Urol 197:246-252

36. Khan SR, Pearle MS, Robertson WG et al (2016) Kidney stones. Nat Rev Dis Primers 2:16008

37. Normand M, Bergua D, Bouvet JP, Cayotte JL, Gottis M (1989) Correlations between the cause and the composition of urinary stones - the interest of morphological and infrared analysis. Ann Biol Clin 7:29-34

38. Daudon M, Doré JC, Jungers P, Lacour B (2004) Changes in stone composition according to age and gender of patients: a multivariate epidemiological approach. Urol Res 32:241-247

39. Daudon M (2005) Epidemiology of nephrolithiasis in France. Ann Urol 39:209-231

40. Moses R, Pais VM Jr, Ursiny M, Prien EL Jr, Miller N, Eisner $\mathrm{BH}$ (2015) Changes in stone composition over the two decades: evaluation of over 10,000 stone analyses. Urolithiasis 43:135-139

41. Soble JJ, Hamilton BD, Streem SB (1999) Ammonium acid urate calculi: a reevaluation of risk factors. J Urol 161:869-873

42. Kuruma H, Arakawa T, Kubo S et al (2006) Ammonium acid urate urolithiasis in Japan. Int J Urol 13:498-501

43. Méria P, Hadjadj H, Jungers P, Daudon M, Members of the Urolithiasis Committee of the French Urological Association (2010) Stone formation and pregnancy: pathophysiological insights gained from morphoconstitutional stone analysis. J Urol 183: $1412-1416$

44. Abate N, Chandalia M, Cabo-Chan AV Jr, Moe OW, Sakhaee K (2004) The metabolic syndrome and uric acid nephrolithiasis: novel features of renal manifestation of insulin resistance. Kidney Int 65:386-392 
45. Williams JC Jr, Saw KC, Paterson RF, Hatt EK, McAteer JA, Lingeman JE (2003) Variability of renal stone fragility in shock wave lithotripsy. Urology 61:1092-1096

46. Daudon M, Bouzidi H, Bazin D (2010) Composition and morphology of phosphate stones and their relation with etiology. Urol Res 38:459-467

47. Mandel N, Mandel I, Fryjoff K, Rejniak T, Mandel G (2003) Conversion of calcium oxalate to calcium phosphate with recurrent stone episodes. J Urol 169:2026-2029

48. Dessombz A, Letavernier E, Haymann JP, Bazin D, Daudon M (2015) Calcium phosphate stone morphology can reliably predict distal renal tubular acidosis. J Urol 193:1564-1569

49. Low RK, Stoller ML (1997) Endoscopic mapping of renal papillae for Randall's plaques in patients with urinary stone disease. J Urol 158:2062-2064
50. Evan AP, Lingeman JE, Coe FL et al (2003) Randall's plaque of patients with nephrolithiasis begins in basement membranes of thin loops of Henle. J Clin Invest 111:607-616

51. Daudon M, Bazin D, Letavernier E (2015) Randall's plaque as the origin of calcium oxalate kidney stones. Urolithiasis 43(S1):5-11

52. Kim SC, Coe FL, Tinmouth WW et al (2005) Stone formation is proportional to papillary surface coverage by Randall's plaque. J Urol 173:117-119

53. Matlaga BR, Williams JC Jr, Kim SC et al (2006) Endoscopic evidence of calculus attachment to Randall's plaque. J Urol 175:1720-1724 